\title{
Assessment of trace metals contamination in Diplodus annularis (Linnaeus, 1758) from the south coast of Sfax, Tunisia
}

\author{
Zohra Ben Salem ${ }^{1} \cdot$ Habib Ayadi $^{1}$
}

Received: 18 August 2016/ Accepted: 12 June 2017/Published online: 21 June 2017

(c) Springer International Publishing AG 2017

\begin{abstract}
Contamination of trace metals in fish is regarded as a major crisis globally, with a large share in many developing countries. On the south coast of Sfax (Tunisia), concentrations of seven trace metals, i.e., cadmium $(\mathrm{Cd})$, copper $(\mathrm{Cu})$, iron $(\mathrm{Fe})$, lead $(\mathrm{Pb})$, mercury $(\mathrm{Hg})$, nickel $(\mathrm{Ni})$ and zinc ( $\mathrm{Zn})$, were evaluated in Diplodus annularis. The sampling was conducted during December 2014. The $\mathrm{Cd}$ and $\mathrm{Zn}$ concentrations were higher than the $\mathrm{FAO} / \mathrm{WHO}$ and WHO permissible limits in all tissues, while $\mathrm{Fe}$ and $\mathrm{Pb}$ concentrations were higher than the WHO permissible limits in the gills and/or liver. The levels of metal accumulation varied between tissues: liver $>$ gills $>$ muscle. The total target hazard quotient (THQ) through consumption of fish, calculated by adding the individual THQs, was above 1 , indicating that there is significant potential health risk associated with the consumption of $D$. annularis. Therefore, intake of sparaillon for the general population is a matter of concern.
\end{abstract}

Keywords D. annularis $\cdot$ Human risk - Sfax south coast . Trace metals

\section{Introduction}

During the past 2 decades, the gulf of Gabes, Tunisia, central Mediterranean coast, has produced more than half of the annual fish yield in Tunisia (Ben Brahim et al. 2010).

Zohra Ben Salem

bensalemzohra@gmail.com

1 Laboratory of Biodiversity and Aquatic Ecosystems UR/ 11ES72, Ecology and Planktonology, Faculty of Sciences of Sfax, University of Sfax, PB 1171, 3000 Sfax, Tunisia
Despite its importance to the economy and for wildlife conservation, the Gulf of Gabes is now undergoing elevated stress caused by urbanization and anthropogenic expansion (Hamza-Chaffai et al. 1997; Ben Salem and Ayadi 2016a). The littoral of Sfax is of great ecological interest. However, the increasing anthropogenic pressure, especially in the southern part, has damaged the marine environment and its biodiversity (Hamza-Chaffai et al. 1999; Tayibi et al. 2009; Drira et al. 2016).

Due to their toxicity and accumulation in biota and fishes, trace metals have received considerable attention, especially in aquatic ecosystems (Barhoumi et al. 2009; Ben Salem and Ayadi 2016b). Trace metals are categorized as non-essential (e.g., $\mathrm{Cd}, \mathrm{Pb}, \mathrm{Hg}$ ) and essential (e.g., $\mathrm{Cu}$, $\mathrm{Fe}, \mathrm{Zn}$ ). Even at low concentrations, non-essential ones can be very harmful for human health when ingested over a long time period. Essential metals can also produce toxic effects after excessive intake (Tuzen 2009).

Fish contribute to good health because of their highquality proteins and omega-3 polyunsaturated fatty acids (Storelli et al. 2006). However, all benefits can be neutralized by fish contamination with trace metals (CastroGonzález and Méndez-Armenta 2008). Therefore, fish consumption can be a major route of human exposure to trace metals (Chen et al. 2010).

Diplodus annularis (Linnaeus, 1758) is a benthopelagic species common on marine bottoms covered by Posidonia seagrass beds (Derbal et al. 2007; Chaouch et al. 2013). D. annularis constitutes one of the most edible and commercial fish species in Tunisia, especially in Sfax city (Ketata Khitouni et al. 2014). Hence, the goals of this study are: (1) to monitor the concentrations of trace metals including cadmium $(\mathrm{Cd})$, copper $(\mathrm{Cu})$, iron $(\mathrm{Fe})$, lead $(\mathrm{Pb})$, mercury $(\mathrm{Hg})$, nickel $(\mathrm{Ni})$ and zinc $(\mathrm{Zn})$ in D. annularis tissues, including the gills, liver and muscle, (2) to evaluate the 
health risks according to tissues' tendency to accumulate these metals and (3) to evaluate the health risks of consumption of $D$. annularis using the non-carcinogenic target hazard quotient (THQ).

\section{Materials and methods}

\section{Study site}

Our study was performed on the south coast of Sfax (between $34^{\circ} \mathrm{N}$ and $10^{\circ} \mathrm{E}$ ), located in southeast Tunisia (southern Mediterranean Sea) (Fig. 1). The south coast of Sfax extends $15 \mathrm{~km}$ and includes part of the city, harbor, solar saltern, and the two industrial areas of Madagascar and Sidi Salem. The amount of effluent discharged was 23,000-30,000 $\mathrm{m}^{3} \mathbf{J}^{-1}$ (Maalej et al. 2002).

\section{Fish sampling and trace metal analysis}

Diplodus annularis was purchased from fishing boats on the south coast of Sfax (a site experiencing anthropogenic pressure) and Luza (a clean site). All specimens were weighed, measured by total length (fish size $13.40 \pm 0.46 \mathrm{~cm}$; fish weight $25.80 \pm 2.73 \mathrm{~g} ; N=10$ ) and kept frozen at $-20{ }^{\circ} \mathrm{C}$ until dissection. For bioaccumulation analysis, the liver, muscle and gills were taken and were prepared as follows: the muscle and liver were removed with stainless-steel utensils and gilled filaments were removed from the gill arch, which was scraped to remove overlying tissues. One gram of each sample was digested with $6 \mathrm{ml}$ $\mathrm{HNO}_{3}(65 \%)$. Digestion was carried out on a hot plate at $103{ }^{\circ} \mathrm{C}$ for about $6 \mathrm{~h}$ until a clear solution was obtained.

\section{Trace metal analysis}

The trace metal concentrations in water and fish tissues were determined with an atomic absorption spectrometer (AAS, PerkinElimer). Metal concentrations were expressed in $\mathrm{mg} \mathrm{kg}^{-1}$ wet weight (WW) for fish or $\mu \mathrm{g}^{-1}$ in the water.

\section{Metal load}

The concentration of a single metal was divided by the mean concentration of that metal measured in tissues of the fish from a clean site (Luza).

The metal load index is calculated using the formula MLs $=\left[\sum(\right.$ Cis/Cir $\left.)\right] / N$ (Bervoets and Blust 2003), where MLs is the relative metal load in a tissue at site $s$, Cis is the concentration of metal $i$ at site $s$, Cir is the concentration of metal $i$ at the reference site $(r)$, and $N$ is the number of metals measured. When $\mathrm{Cis}<\mathrm{Cir}$, the (Cis/Cir) was considered 1 . Thus, the relative $\mathrm{ML}$ is a measure of the enrichment of the tissue with the measured metals compared to those in fish from the clean site. As a consequence, when no enrichment occurred, $\mathrm{ML}=1$.

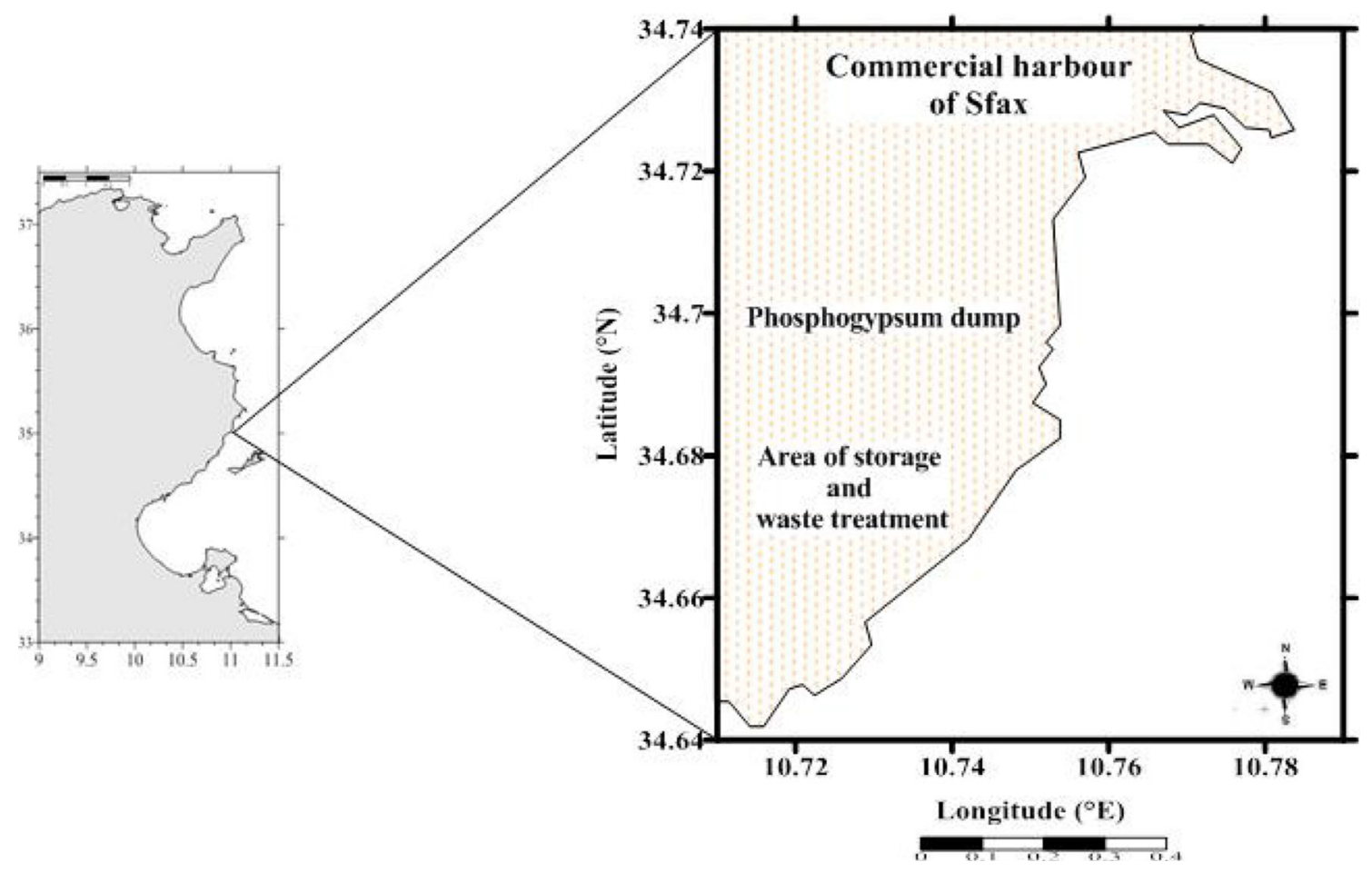

Fig. 1 Location map of the study area, south coast of Sfax 


\section{Health risk from fish consumption}

The non-carcinogenic health risks associated with the consumption of $D$. annularis were assessed based on the target hazard quotients (THQs), and calculations were made using the following equation (Yi et al. 2011),

$\mathrm{THQ}=\frac{E_{\mathrm{f}} \times E_{\mathrm{d}} \times F_{\mathrm{ir}} \times C}{R_{\mathrm{fd}} \times W_{\mathrm{ab}} \times T_{\mathrm{a}}} \times 10^{-3}$,

where THQ is the target quotient, $E_{\mathrm{f}}$ the exposure frequency (365 day year $\left.{ }^{-1}\right), \quad E_{\mathrm{d}}$ the exposure duration (70 years, average lifetime), $F_{\text {ir }}$ the food ingestion rate $\left(\mathrm{g} \mathrm{day}^{-1}\right), C$ the the trace metal concentration in fish $\left(\mathrm{mg} \mathrm{g}^{-1}\right)$ and $R_{\mathrm{fd}}$ the oral reference dose $\left(\mathrm{mg} \mathrm{kg}^{-1}\right.$ day $\left.^{-1}\right)$, based on $1 \times 10^{-3}, 3 \times 10^{-1}, 4 \times 10^{-2}, 4 \times 10^{-3}$, $11 \times 10^{-3}$ and $16 \times 10^{-4} \mathrm{mg} \mathrm{kg}^{-1} \mathrm{day}^{-1}$ for $\mathrm{Cd}, \mathrm{Zn}, \mathrm{Cu}$, $\mathrm{Ni}, \mathrm{Hg}$ and $\mathrm{Pb}$, respectively (USEPA 2000). $W_{\mathrm{ab}}$ is the average adult body weight $(65 \mathrm{~kg})$ and $T_{\mathrm{a}}$ the average exposure time for non-carcinogens (365 days year ${ }^{-1} \times$ number of exposure years, assuming 70 years).

The daily intake of fish in Tunisia is $39 \mathrm{~kg}_{\text {person }}{ }^{-1}$ year $^{-1}$ (INS, 2010, in Dhraief et al. 2013), and the estimated food ingestion rate is $50 \mathrm{~g} \mathrm{day}^{-1}$. A THQ value below 1 (THQ <1) indicates no obvious risk, and a THQ value equal to or higher than 1 (THQ $\leq 1$ ) indicates a concern regarding health risks.

The total THQ is calculated as the arithmetic sum of the individual metal THQ value, derived by the method of Chien et al. (2002).

Total THQ $=$ THQ $($ metal 1$)+$ THQ $($ metal 2$)+$ THQ $($ metal 3$)+\cdots+$ THQ (metal $n)$. It was further assumed that cooking has no effect on the toxicity of trace metals in seafood (Cooper et al. 1991; Chien et al. 2002).

\section{Data analysis}

The results were expressed as mean $\pm \mathrm{SD}$. The Tukey test was used to examine the difference in trace metal concentrations in tissues as indicated by different case letters in descending order, $\mathrm{a}, \mathrm{b}$ and $\mathrm{c}$ at $P<0.01$. The data were statistically analyzed using the Statistical Package for the Social Sciences software (SPSS, version 20).

\section{Results}

\section{Trace metal concentrations in sparaillon tissues}

The mean concentrations of trace metals $(\mathrm{Cd}, \mathrm{Cu}, \mathrm{Fe}, \mathrm{Hg}$, $\mathrm{Ni}, \mathrm{Pb}$ and $\mathrm{Zn}$ ) in the liver, gills and muscle of $D$. annularis are presented in Table 1. Distribution patterns of metal concentrations in $D$. annularis tissues follow the sequence: $\mathrm{Cu}<\mathrm{Ni}<\mathrm{Cd}<\mathrm{Pb}<\mathrm{Hg}<\mathrm{Fe}<\mathrm{Zn}$ in the gills,
$\mathrm{Pb}<\mathrm{Hg}<\mathrm{Ni}<\mathrm{Cu}<\mathrm{Cd}<\mathrm{Fe}<\mathrm{Zn}$ in the liver and $\mathrm{Cu}<\mathrm{Pb}<\mathrm{Hg}<\mathrm{Ni}<\mathrm{Cd}<\mathrm{Fe}<\mathrm{Zn}$ in the muscle. Trace metal concentrations in the gills and liver were higher when compared with muscle.

\section{Metal load}

The mean relative metal loads for the individual metal per tissue are given in Fig. 2. The metal load exceeded 1 in all tissues of $D$. annularis, except $\mathrm{ML} j \mathrm{Cd}$ in the liver. The analysis of the metal load index in muscle remains very important given that it is destined for human consumption. The muscle $\mathrm{ML} j$ values decreased in following order: $\mathrm{Fe}>\mathrm{Pb}>\mathrm{Zn}>\mathrm{Cd}>\mathrm{Cu}>\mathrm{Hg}$.

\section{Health risk assessment}

The estimated THQ values for individual metals and the total THQ from consumption of fish by the general population from the south coast of Sfax are shown in Fig. 3. The THQs of the studied metals are below 1, indicating that people would not experience significant health risks from the intake of individual metals through sparaillon consumption. The estimated THQ for individual metals decreased in the following sequence: $\mathrm{Hg}>\mathrm{Cd}>\mathrm{Zn}>\mathrm{Ni}>\mathrm{Pb}>\mathrm{Cu}$. The total THQ for the general population exceeded the classification of the no risk level (total THQ $>1$ ), recommended by the USEPA (2000) (Fig. 3). Mercury is the major risk contributor, accounting for $48 \%$ of the total THQ, followed by $\mathrm{Cd}$ and $\mathrm{Zn}$, contributing 33 and 15\%, respectively (Fig. 4).

\section{Discussion}

When exposed to elevated metal levels in an aquatic environment, fish can absorb and bio-accumulate the available metals directly from their surrounding environment via gills or through the ingestion of contaminated food (Tkatcheva et al. 2004). Once incorporated into the fish body, trace metals were partitioned among different tissues via a process that depends on biological needs (Zubcov et al. 2012). Therefore, the ability of tissues to either regulate or accumulate metals can be directly related to the quantity of metal accumulated in each tissue. Furthermore, physiological differences and the position of each fish tissue within the aquatic environment can also influence the bio-accumulation of a specific metal (ElMoselhy et al. 2014).

The lowest cadmium content was $0.76 \mathrm{mg} \mathrm{kg}^{-1}$ ww in muscle, while the highest cadmium content was $3.01 \mathrm{mg} \mathrm{kg}^{-1}$ ww in liver. The maximum cadmium level permitted for sea fishes is $1 \mathrm{mg} \mathrm{kg}{ }^{-1}$ ww according to WHO (1989) and $0.5 \mathrm{mg} \mathrm{kg}^{-1}$ ww according to FAO/ 
Table 1 Heavy metal contents (milligram per kilogram wet weight) in different tissues of $D$. annularis

\begin{tabular}{llllllll}
\hline & $\mathrm{Cd}$ & $\mathrm{Cu}$ & $\mathrm{Fe}$ & $\mathrm{Hg}$ & $\mathrm{Ni}$ & $\mathrm{Pb}$ & $\mathrm{Zn}$ \\
\hline Permissible limits & $1^{\mathrm{A}}, 0.5^{\mathrm{B}}$ & $30^{\mathrm{A}, \mathrm{B}}$ & $100^{\mathrm{A}}$ & & $0.5-1^{\mathrm{A}}$ & $2^{\mathrm{A}}, 0.5^{\mathrm{B}}$ & $100^{\mathrm{A}}, 40^{\mathrm{B}}$ \\
Gills & $1.84 \pm 0.05^{\mathrm{b}}$ & $0.34 \pm 0.08^{\mathrm{b}}$ & $104.30 \pm 0.08^{\mathrm{b}}$ & $5.46 \pm 0.08^{\mathrm{c}}$ & $0.66 \pm 0.10^{\mathrm{b}}$ & $1.97 \pm 0.05^{\mathrm{c}}$ & $137 \pm 0.03^{\mathrm{a}}$ \\
Liver & $3.01 \pm 0.11^{\mathrm{c}}$ & $1.69 \pm 0.02^{\mathrm{c}}$ & $240.80 \pm 0.11^{\mathrm{c}}$ & $0.39 \pm 0.05^{\mathrm{b}}$ & $0.90 \pm 0.14^{\mathrm{c}}$ & $0.28 \pm 0.05^{\mathrm{b}}$ & $275 \pm 0.10^{\mathrm{c}}$ \\
Muscle & $0.76 \pm 0.02^{\mathrm{a}}$ & $0.11 \pm 0.02^{\mathrm{a}}$ & $15.83 \pm 1.09^{\mathrm{a}}$ & $0.20 \pm 0.11^{\mathrm{a}}$ & $0.35 \pm 0.07^{\mathrm{a}}$ & $0.17 \pm 0.01^{\mathrm{a}}$ & $135.77 \pm 2.43^{\mathrm{a}}$ \\
\hline
\end{tabular}

Different letters indicate significant differences between tissues $\mathrm{a}<\mathrm{b}<\mathrm{c},(P<0.05)$

A WHO (1989)

${ }^{\text {B }}$ FAO/WHO (1989)

Fig. 2 Metal load index in the gills, liver and muscle of $D$. annularis

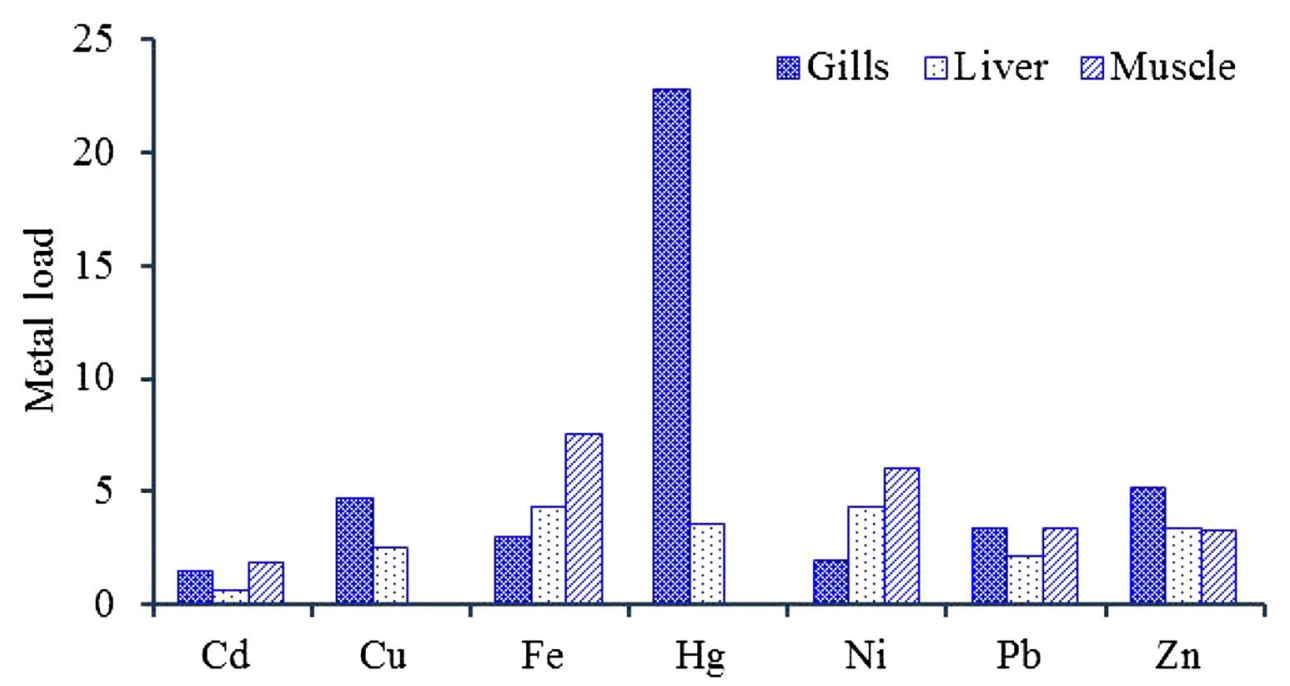

$\mathrm{Cu} \boxminus \mathrm{Pb}$ 网 $\mathrm{Ni} \cap \mathrm{Zn} \otimes \mathrm{Cd} \otimes \mathrm{Hg}$

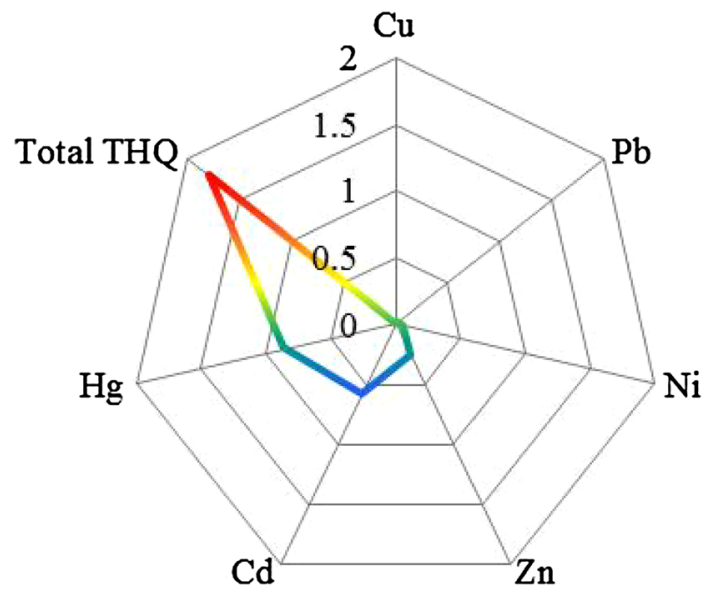

Fig. 3 Estimated target hazard quotients (THQs) for individual metals and total THQ from consumption of $D$. annularis

WHO (1989). Cadmium levels in all analyzed tissues were found to be higher than these legal limits.

The lowest and highest copper levels in $D$. annularis tissues were $0.11 \mathrm{mg} \mathrm{kg}^{-1}$ ww in muscle and $1.69 \mathrm{mg} \mathrm{kg}^{-1} \mathrm{ww}$ in liver. The maximum copper level permitted for fishes is $30 \mathrm{mg} \mathrm{kg}^{-1}$ ww according to the

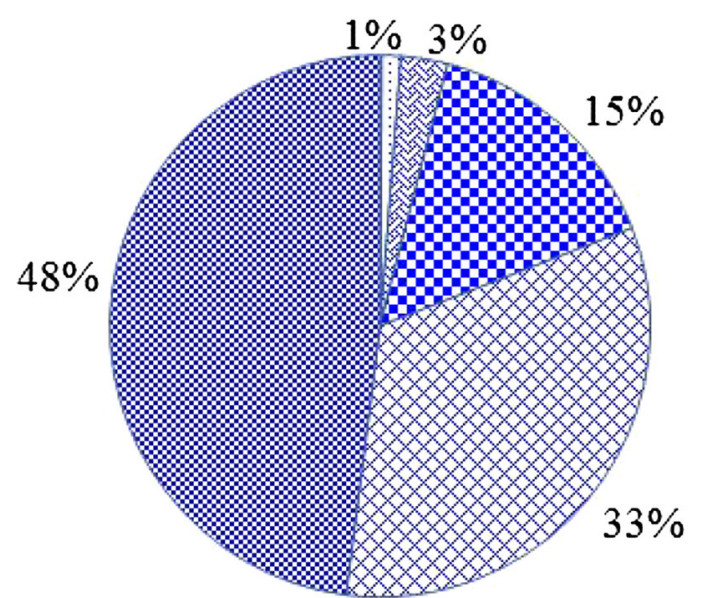

Fig. 4 Composition of the relative contribution of THQ by $\mathrm{Cu}, \mathrm{Cd}$, $\mathrm{Ni}, \mathrm{Pb}$ and $\mathrm{Zn}$ from consuming $D$. annularis from the south coast of Sfax

World Health Organization (FAO/WHO 1989; WHO 1989). Copper levels in all analyzed tissues were found to be lower than the legal limits. 
The lowest and highest iron levels in $D$. annularis tissues were $15.83 \mathrm{mg} \mathrm{kg}^{-1}$ ww in muscle and $240.80 \mathrm{mg} \mathrm{kg}^{-1}$ ww in liver. The maximum iron level permitted for fishes is $100 \mathrm{mg} \mathrm{kg}^{-1}$ ww according to WHO (1989). Iron levels in the liver $\left(240.80 \mathrm{mg} \mathrm{kg}^{-1} \mathrm{ww}\right)$ and gills (104.30) were found to be higher than these legal limits.

The minimum and maximum lead levels observed were $0.17 \mathrm{mg} \mathrm{kg}^{-1} \mathrm{ww}$ in muscle and $1.97 \mathrm{mg} \mathrm{kg}^{-1} \mathrm{ww}$ in gills. The maximum lead levels permitted for sea fishes are $0.5 \mathrm{mg} \mathrm{kg}^{-1} \mathrm{ww}$ according to WHO (1989) and $2 \mathrm{mg} \mathrm{kg}^{-1}$ ww according to FAO/WHO (1989). Lead levels in gills were found to be higher than these legal limits (WHO 1989).

The lowest mercury content was $0.20 \mathrm{mg} \mathrm{kg}^{-1}$ ww in muscle, while the highest mercury content was $5.46 \mathrm{mg} \mathrm{kg}^{-1}$ ww in gills. There is no information about the maximum mercury levels in fish samples from the World Health Organization. Mercury contents in the literature have been reported in the range of $0.06-0.31 \mathrm{mg} \mathrm{kg}^{-1} \mathrm{ww}$ in fish samples from Sicily (Mediterranean Sea) (Copat et al. 2012), $0.08-0.12 \mathrm{mg} \mathrm{kg}^{-1}$ ww in Mugil cephalus from the Black Sea (Stancheva et al. 2013) and 0.01-0.10 $\mathrm{mg} \mathrm{kg}^{-1} \mathrm{ww}$ in commercial fish from the Sultanate of Oman (Al-Busaidi et al. 2011). Our mercury values are higher than those reported in the literature.

The lowest and highest zinc levels in $D$. annularis tissues were $135.77 \mathrm{mg} \mathrm{kg}^{-1} \mathrm{ww}$ in muscle and $275 \mathrm{mg} \mathrm{kg}^{-1} \mathrm{ww}$ in liver. The maximum zinc levels permitted for fishes are $40 \mathrm{mg} \mathrm{kg}^{-1} \mathrm{ww}$ according to FAO/WHO (1989) and $100 \mathrm{mg} \mathrm{kg}^{-1}$ ww according to WHO (1989). Zinc levels in $D$. annularis tissues were found to be higher than limits established by the World Health Organization.

The lowest and highest nickel levels in $D$. annularis tissues were $0.35 \mathrm{mg} \mathrm{kg}^{-1}$ ww in muscle and $0.90 \mathrm{mg} \mathrm{kg}^{-1} \mathrm{ww}$ in liver. Nickel concentrations were in the range of the permitted limits $\left(0.5-1 \mathrm{mg} \mathrm{kg}^{-1} \mathrm{ww}\right)$ established by FAO/WHO (1989) in all analyzed tissues.

Trace metals such as $\mathrm{Cu}, \mathrm{Fe}$ and $\mathrm{Zn}$ are essential for fish metabolism; however, in cases when concentrations exceed normal levels in the environment, they become toxic (Wei et al. 2014). Non-essential metals such as $\mathrm{Cd}, \mathrm{Hg}, \mathrm{Ni}$ and $\mathrm{Pb}$ have no biological function and are toxic even at low concentrations (Ivanović et al. 2016). Our results showed that trace metal bioaccumulation varied significantly among tissues. The highest concentrations of $\mathrm{Cd}, \mathrm{Cu}, \mathrm{Fe}, \mathrm{Ni}$ and $\mathrm{Zn}$ were recorded in the liver, while the highest concentrations of $\mathrm{Hg}$ and $\mathrm{Pb}$ were found in the gills. Studies carried out with various fish species have shown that metal accumulation is generally more pronounced in the liver and gills than in muscle, as active metabolite organs accumulate higher amounts of trace metals than muscle (Karadede-Akin and Ünlü 2007; Al-Yousuf et al. 2000). Similar results were reported in previous studies comparing metal concentrations in muscle to others tissues (Norouzi et al. 2012; El-Moselhy et al. 2014; Dwivedi et al. 2015).

The metal load values exceeded 1 (ML $>1$ ), especially in muscle tissue. The average ML increased in the following sequence: $\mathrm{Cd}<\mathrm{Pb}<\mathrm{Cu}<\mathrm{Zn}<\mathrm{Ni}<\mathrm{Fe}<\mathrm{Hg}$. These results highlight the enrichment of $D$. annularis with trace metals compared to the less contaminated Luza zone.

Risk assessment is one of the fastest methods to evaluate hazard impacts on human health and is also needed to determine the levels of treatment that will tend to solve the environmental problems occurring in daily life (Ersoya and Celik 2009). Health risks for the general population of the south coast of Sfax from the consumption of D. annularis were assessed by estimating the target hazard quotient (THQ). THQ values greater than 1 indicate that a potential health risk may occur. Our results demonstrated that the THQ of individual metals did not pose a potential risk, but the total THQ exceeded the classification of no risk level (total THQ $>1$ ), as recommended by the USEPA (2000), suggesting direct health effects may be significant for the general population and especially for local inhabitants (Huang et al. 2008; Krishna et al. 2014; Li et al. 2015). Thus, constant monitoring of both essential and non-essential metals remains very important to evaluate the risk for people consuming contaminated fish from the study area—and what can be done to lower this risk.

\section{Conclusion}

When considering the trace metal concentrations in fish, the most important aspect is their toxicity to humans after consumption. The present results revealed that the concentrations of $\mathrm{Cd}, \mathrm{Pb}, \mathrm{Fe}$ and $\mathrm{Zn}$ in $D$. annularis tissues were above the permissible limits established by the World Health Organization (WHO, FAO/WHO) for human consumption. The contamination levels of $D$. annularis from the south coast of Sfax were high compared to a less contaminated zone (Luza). The total THQ indeed suggested that human consumption of D. annularis is of great concern for public health.

Acknowledgements This work was supported by the Biodiversity and Aquatic Ecosystems UR/11ES72 research unit, Faculty of Sciences of Sfax (Tunisia).

\section{Compliance with ethical standards}

Conflict of interest The authors declare that they have no conflict of interest.

\section{References}

Al-Busaidi M, Yesudhason P, Al-Mughairi S et al (2011) Toxic metals in commercial marine fish in Oman with reference to 
national and international standards. Chemosphere 85:67-73. doi:10.1016/j.chemosphere.2011.05.057

Al-Yousuf MH, El-Shahawi MS, Al-Ghais (2000) Trace metals in liver, skin and muscle of Lethrinus lentjan fish species in relation to body length and sex. Sci Total Environ 256:87-94

Barhoumi S, Messaoudi I, Deli T et al (2009) Cadmium bioaccumulation in three benthic fish species, Salaria basilisca, Zosterisessor ophiocephalus and Solea vulgaris collected from the Gulf of Gabes in Tunisia. J Environ Sci 21:980-984. doi:10.1016/S10010742(08)62371-2

Ben Brahim M, Hamza A, Hannachi I et al (2010) Variability in the structure of epiphytic assemblages of Posidonia oceanica in relation to human interferences in the Gulf of Gabes, Tunisia. Mar Environ Res 70:411-421. doi:10.1016/j.marenvres.2010.08. 005

Ben Salem Z, Ayadi H (2016a) Assessment of heavy metal contamination levels and toxicity in sediments and fishes from the Mediterranean Sea (southern coast of Sfax, Tunisia). Environ Sci Pollut Res 23:13954-13963. doi:10.1007/s11356-016-6534-3

Ben Salem Z, Ayadi H (2016b) Heavy metal accumulation in Diplodus annularis, Liza aurata, and Solea vulgaris relevant to their concentration in water and sediment from the southwestern Mediterranean (coast of Sfax). Environ Sci Pollut Res 23:13895-13906. doi:10.1007/s11356-016-6531-6

Bervoets L, Blust R (2003) Metal concentrations in water, sediment and gudgeon (Gobio gobio) from a pollution gradient: relationship with fish condition factor. Environ Pollut 126:9-19. doi:10. 1016/S0269-7491(03)00173-8

Castro-González MI, Méndez-Armenta M (2008) Heavy metals: implications associated to fish consumption. Environ Toxicol Pharmacol 26:263-271. doi:10.1016/j.etap.2008.06.001

Chaouch H, Hamida-Ben Abdallah O, Ghorbel M, Jarboui O (2013) Reproductive biology of the annular seabream, Diplodus annularis (Linnaeus, 1758), in the Gulf of Gabes (Central Mediterranean). J Appl Ichthyol 29:796-800

Chen B-C, Chou W-C, Chen W-Y, Liao C-M (2010) Assessing the cancer risk associated with arsenic-contaminated seafood. J Hazard Mater 181:161-169. doi:10.1016/j.jhazmat.2010.04. 112

Chien LC, Hung TC, Choang KY et al (2002) Daily intake of TBT, $\mathrm{Cu}, \mathrm{Zn}, \mathrm{Cd}$ and As for fishermen in Taiwan. Sci Total Environ 285:177-185

Cooper CB, Doyle ME, Kipp K (1991) Risk of consumption of contaminated seafood, the Quincy Bay Case Study. Environ Health Perspect 90:133-140

Copat C, Bella F, Castaing M et al (2012) Heavy metals concentrations in fish from Sicily (Mediterranean Sea) and evaluation of possible health risks to consumers. Bull Environ Contam Toxicol 88:78-83. doi:10.1007/s00128-011-0433-6

Derbal F, Nouacer S, Kara MH (2007) Composition et variations du régime alimentaire du sparaillon Diplodus annularis (Sparidae) du golfe d'Annaba (Est de l'Algérie). Cybium 31:443-450

Dhraief MZ, Oueslati M, Dhehibi B (2013) Income, education and age effects on meat and fish demand in Tunisia. Int J Food Agric Econ 1:1-12

Drira Z, Kmiha-Megdiche S, Sahnoun H et al (2016) Assessment of anthropogenic inputs in the surface waters of the southern coastal area of Sfax during spring (Tunisia, Southern Mediterranean Sea). Mar Pollut Bull 104:355-363. doi:10.1016/j. marpolbul.2016.01.035

Dwivedi AC, Tiwari A, Mayank P (2015) Seasonal determination of heavy metals in muscle, gill and liver tissues of Nile tilapia, Oreochromis niloticus (Linnaeus, 1758) from the tributary of the Ganga River, India. Zool Ecol 25:166-171. doi:10.1080/ 21658005.2015.1020012
El-Moselhy KM, Othman AI, Abd El-Azem H, El-Metwally MEA (2014) Bioaccumulation of heavy metals in some tissues of fish in the Red Sea, Egypt. Egypt J Basic Appl Sci 1:97-105. doi:10. 1016/j.ejbas.2014.06.001

Ersoya B, Celik M (2009) Essential elements and contaminants in tissues of commercial pelagic fish from the Eastern Mediterranean Sea. J Sci Food Agric 89:1615-1621

FAO/WHO (1989) Evaluation of certain food additives and the contaminants mercury, lead and cadmium. WHO Technical Report Series

Hamza-Chaffai A, Amiard-Triquet C, El Abed A (1997) Metallothionein-like protein: is it an efficient biomarker of metal contamination? A case study based on fish from the Tunisian coast. Arch Environ Contam Toxicol 33:53-62. doi:10.1007/ s002449900223

Hamza-Chaffai A, Amiard JC, Cosson RP (1999) Relationship between metallothioneins and metals in a natural population of the clam Ruditapes decussatus from Sfax coast: a non-linear model using Box-Cox transformation. Comp Biochem Physiol Part C Pharmacol Toxicol Endocrinol 123:153-163

Huang C, Hsu C, Liu S, Linshiau S (2008) Neurotoxicological mechanism of methylmercury induced by low-dose and longterm exposure in mice: oxidative stress and down-regulated $\mathrm{Na}^{+}$/ $\mathrm{K}^{+}$-ATPase involved. Toxicol Lett 176:188-197. doi:10.1016/j. toxlet.2007.11.004

Ivanović J, Janjić J, Baltić M et al (2016) Metal concentrations in water, sediment and three fish species from the Danube River, Serbia: a cause for environmental concern. Environ Sci Pollut Res. doi:10.1007/s11356-016-6875-y

Karadede-Akin H, Ünlü E (2007) Heavy metal concentrations in water, sediment, fish and some benthic organisms from Tigris River, Turkey. Environ Monit Assess 131:323-337. doi:10.1007/ s10661-006-9478-0

Ketata Khitouni I, Boudhrioua Mihoubi N, Bouain A, Ben Rebah F (2014) Accumulation of $\mathrm{Hg}, \mathrm{Pb}, \mathrm{Cr}$, and $\mathrm{Fe}$ in muscle and head of four fish species: Diplodus annularis, Zosterisessor ophiocephalus, Liza aurata and Caranx rhonchus. J Adv Biol 5:1-559

Krishna PV, Jyothirmayi V, Rao KM (2014) Human health risk assessment of heavy metal accumulation through fish consumption, from Machilipatnam Coast, Andhra Pradesh, India. Int Res J Public Environ Health 1:121-125

Li P, Zhang J, Xie H et al (2015) Heavy metal bioaccumulation and health hazard assessment for three fish species from Nansi Lake, China. Bull Environ Contam Toxicol 94:431-436. doi:10.1007/ s00128-015-1475-y

Maalej S, Mahjoub A, Kammoun A, Bakhrouf F (2002) Motile aeromonas: which 484 spatial and temporal evolution in an urban effluent and in coastal marine environment? Rev Water Sci 15:273-287

Norouzi M, Mansouri B, Hamidian AH et al (2012) Metal concentrations in tissues of two fish species from Qeshm Island, Iran. Bull Environ Contam Toxicol 89:1004-1008. doi:10.1007/ s00128-012-0809-2

Stancheva M, Makedonski L, Petrova E (2013) Determination of heavy metals $(\mathrm{Pb}, \mathrm{Cd}$, As and $\mathrm{Hg}$ ) in black sea grey mullet (Mugil cephalus). Bulg J Agric Sci 19:30-34

Storelli MM, Barone G, Storelli A, Marcotrigiano GO (2006) Trace metals in tissues of Mugilids (Mugil auratus, Mugil capito, and Mugil labrosus) from the Mediterranean Sea. Bull Environ Contam Toxicol 77:43-50. doi:10.1007/s00128-006-1030-y

Tayibi H, Choura M, López FA et al (2009) Environmental impact and management of phosphogypsum. J Environ Manag 90:2377-2386. doi:10.1016/j.jenvman.2009.03.007

Tkatcheva V, Hyvärinen H, Kukkonen J et al (2004) Toxic effects of mining effluents on fish gills in a subarctic lake system in NW 
Russia. Ecotoxicol Environ Saf 57:278-289. doi:10.1016/S01476513(03)00079-4

Tuzen M (2009) Toxic and essential trace elemental contents in fish species from the Black Sea, Turkey. Food Chem Toxicol 47:1785-1790. doi:10.1016/j.fct.2009.04.029

USEPA (2000) Risk-based concentration table. United States Environmental Protection Agency, Philadelphia

Wei Y, Zhang J, Zhang D et al (2014) Metal concentrations in various fish organs of different fish species from Poyang Lake, China. Ecotoxicol Environ Saf 104:182-188. doi:10.1016/j.ecoenv. 2014.03.001
WHO (1989) Heavy metals environmental aspects. Environment Health Criteria, Geneva

Yi Y, Yang Z, Zhang S (2011) Ecological risk assessment of heavy metals in sediment and human health risk assessment of heavy metals in fishes in the middle and lower reaches of the Yangtze River basin. Environ Pollut 159:2575-2585. doi:10.1016/j. envpol.2011.06.011

Zubcov E, Zubcov N, Ene A, Biletchi L (2012) Assessment of copper and zinc levels in fish from freshwater ecosystems of Moldova. Environ Sci Pollut Res 19:2238-2247. doi:10.1007/s11356-0110728-5 